Environmental Biology of Fishes, Vol. 24, No. 4, 1989, pp. 287-293.

ISSN: 0378-1909

DOI: $10.1007 / \mathrm{BF} 00001402$

http://www.springerlink.com/

http://www.springerlink.com/content/v50w739260228h27/fulltext.pdf

(C) Springer. The original publication is available at www.springerlink.com

\title{
Behavior of fish predators and their prey: habitat choice between open water and dense vegetation
}

\author{
Jacqueline F. Savino \& Roy A. Stein \\ Ohio Cooperative Fish and Wildlife Research Unit ${ }^{2}$, Department of Zoology, The Ohio State University. \\ ${ }^{2}$ The unit is sponsored jointly by the United States Fish and Wildlife Service, Ohio Department of Natural \\ Resources, The Ohio State University, and the Wildlife Management Institute
}

\section{Synopsis}

Behavior of largemouth bass, Micropterus salmoides, and northern pike, Esox lucius, foraging on fathead minnows, Pimephales promelas, or bluegills, Lepomis macrochirus, was quantified in pools with $50 \%$ cover (half the pool had

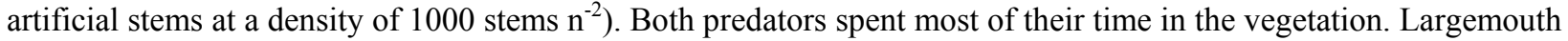
bass searched for bluegills and ambushed minnows, whereas the relatively immobile northern pike ambushed all prey. Minnows were closer to predators and were captured more frequently than bluegills. Even when minnows dispersed, they moved continually and eventually wandered within striking distance of a predator. Bluegills dispersed in the cover with predators. Bass captured the few bluegills that strayed into the open and pike captured those that approached too closely in the cover. The ability of predators to capture prey while residing in habitats containing patches of dense cover may explain their residence in areas often considered to be poor ones for foraging.

\section{Introduction}

Aquatic vegetation in littoral zones of north temperate lakes provides areas with varying degrees of structural complexity where several species of predators and prey commonly reside. Many laboratory studies on the effect of density of plants or other cover on predator-prey interactions have concentrated on changes in foraging success (Glass 1971, Mauck \& Coble 1971, Minello \& Zimmerman 1983, Saiki \& Tash 1979, Savino \& Stein 1982, Tomcko et al. 1984, Schramm \& Zale 1985). In the field, investigators have measured changes in growth rates or condition of predators (Crowder \& Cooper 1979, Colle \& Shireman 1980) or changes in prey densities (Saiki \& Tash 1979, Gilinski 1984) with changes in plant density or abundance. No study, however, has dealt with changes in the behavior of foragers and prey offered a choice of habitat. To better understand how littoral areas affect foraging success and behavior of predators, we quantified the behavioral interactions of two piscivorous fishes and their prey in environments with heterogeneous cover.

Predator behavior and predation rate both change with habitat structure and with the species of predator and prey (Savino \& Stein 1988). Predators differ in their foraging behaviors; largemouth bass, Micropterus salmoides, distinguish among prey types and adjust their attack behaviors accordingly (Nyberg 1971), whereas northern pike, Esox lucius, usually stalk and attack only nearby prey (Hobson 1979). Both species commonly live in or near vegetation in the littoral zone (Diana et al. 1977, Fish \& Savitz 1983, Chapman \& Mackay 1984). Yet during laboratory studies (Savino \& Stein 1988), neither predator was able to capture a prey (bluegill, 
Lepomis macrochirus) common in habitats of high plant density (Mittelbach 1981, Werner et al. 1983). The fathead minnow, Pimephales promelas, is another widespread forage fish that uses vegetation (Sullivan \& Atchison 1978) but does not co-occur in large numbers with predators (Tonn \& Magnuson 1982, Rahel 1984), suggesting that it is more vulnerable to predators. Appropriate antipredator behavior enables prey to reduce susceptibility to predators. When suitable structure is available, crayfish (Orconectes spp.) hide to reduce their vulnerability to smallmouth bass, Micropterus dolomieui, (Stein 1977) or largemouth bass (Saiki \& Tash 1979, Butler \& Stein 1985). Heterogeneous environments provide a choice of habitats and, coupled with behavioral options, may further enhance the ability of prey to avoid predation. We explore the effect of heterogeneity in modifying the foraging succes of largemouth bass and northern pike, as determined by foraging strategy and prey response of bluegills or fathead minnow in short-term, behavioral experiments in laboratory pools with artificial vegetation.

\section{Methods}

To determine how macrophyte cover influences foraging success of piscivorous fish and escape behaviors of their prey, we conducted $1 \mathrm{~h}$ observational experiments in shaded outdoor pools $(0.5 \mathrm{~m}$ deep, $2.4 \mathrm{~m}$ in diameter, white walls). Yellow polypropylene lines $(0.5 \mathrm{~m}$ long, 4 $\mathrm{mm}$ in diameter), simulating plant stems, were fastened at one end to wire mesh and covered with gravel, and with the other end at the water surface. Periphyton on the line caused it to closely resemble natural vegetation. Each pool provided $50 \%$ cover with half of the pool containing the artifical vegetation at 1000 stems $\mathrm{m}^{-2}$, creating a patch of dense cover at 1000 stems $\mathrm{m}^{-2}$ and an overall stem density in the pool of $500 \mathrm{stems} \mathrm{m}^{-2}$. Results of predator-prey interactions in this $50 \%$ cover will be compared to those in $100 \%$ cover with 250 and 1000 stems $\mathrm{m}^{-2}$ used previously by Savino \& Stein $(1982,1988)$. Temperatures in pools averaged $20 \pm 2^{\circ} \mathrm{C}$ and dissolved oxygen was maintained at $7 \mathrm{mgO}_{2} 1^{-1}$.

Feeding behaviour and success of largemouth bass and northern pike $(23-27 \mathrm{~cm}$ total length) were monitored continuously during experiments that began after 35 naive prey (acclimated in a $1 \mathrm{~m}^{2}$ cage for $5 \mathrm{~min}$ ) were released into the area of cover in a pool containing one predator that had been deprived of food for $24 \mathrm{~h}$. We tested bluegills $(35-45 \mathrm{~mm})$ and fathead minnows $(50-60 \mathrm{~mm})$ with each predator type. Prey densities $\left(\right.$ about $8 \mathrm{~m}^{-2}$ ) were within the range of those commonly found in ponds or littoral areas of lakes (Ming 1974, Hackney 1979). We observed predators and prey from ladders $2 \mathrm{~m}$ high; predator behaviors were entered directly into a Datamyte 900 event recorder. Predator behaviors were defined as in Savino \& Stein (1982):

(1) Searching - moving but not orienting towards prey,

(2) Following - moving and orienting towards prey,

(3) Pursuing - following prey at burst speed,

(4) Attacking - striking at prey,

(5) Capturing - engulfing and handling prey, and

(6) Motionless - no movement. We also noted whether the predator seemed to be watching prey. Activity was the sum of all active behaviors, i.e. searching, following, pursuing, attacking, and capturing. Visual contact was the sum of all behaviors included in the observation of prey, i.e. following, pursuing, attacking, capturing, and motionless (but nevertheless observing prey).

Prey behavior (recorded as the percent of prey performing a certain behavior at the time of the observation) and estimated distance (nearest $0.1 \mathrm{~m}$ ) between predator and closest prey not 
attacked were recorded during predator experiments by a second observer at 5 min intervals during the $1 \mathrm{~h}$ experiment. Prey behaviors were as follows:

(1) Schooled - aggregations of individuals moving about as a unit.

(2) Dispersed - individuals not associating strongly with one another. Behavior and distance from the predator of prey that were attacked also were recorded. In addition, the behaviors of blue-gills and fathead minnows were quantified in $1 \mathrm{~h}$ experiments in the absence of a predator. After observing predator-prey interactions during the $1 \mathrm{~h}$ experiment, both species were left in the pool to obtain a daily foraging rate; after $24 \mathrm{~h}$, prey were removed and counted. This approach integrated crepuscular feeding activity, while allowing for direct initial behavioral observations (Sullivan \& Atchison 1978, Savino \& Stein 1982).

Feeding experiments were replicated eight times with largemouth bass ( $\mathrm{n}=4$ bass) and six times with northern pike ( $\mathrm{n}=3$ pike) for each prey type. Predators were used twice with each prey type. Analysis of variance (ANOVA, df $=3$ with large-mouth bass, $\mathrm{df}=2$ with northern pike) in each cover for two major behaviors (capture, activity) showed no significant differences $(\mathrm{P}>0.05)$ among individuals. As no individual consistently differed from others in these behaviors, data were combined for analysis.

Table 1. Frequency or duration of behaviors (medians and 95\% confidence intervals) for predators during feeding experiments in $50 \%$ cover. $\mathrm{P}=$ significance of difference in results with minnows or bluegills as prey: $*=\mathrm{P} \leq 0.05,-$ $=\mathrm{P}>0.05$. For each prey species, 8 experiments were conducted with largemouth bass and 6 with northern pike.

\begin{tabular}{|c|c|c|c|c|c|c|}
\hline \multirow[t]{2}{*}{ Behavior } & \multicolumn{3}{|c|}{ Largemouth bass } & \multicolumn{3}{|c|}{ Northern pike } \\
\hline & Bluegill & Minnow & $\mathrm{P}$ & Bluegill & Minnow & $\mathrm{P}$ \\
\hline Captures per hour & $4(2-6)$ & $4(2-4)$ & - & $1(0-2)$ & $2(0-3)$ & - \\
\hline Captures per day & $7(5-12)$ & $16(12-20)$ & * & $6(5-8)$ & $10(5-17)$ & - \\
\hline Follows per hour & $16(9-18)$ & $14(12-20)$ & - & $1(0-2)$ & $0(0-10)$ & - \\
\hline Attacks per hour & $7(3-10)$ & $6(4-8)$ & - & $1(0-2)$ & $2(0-4)$ & - \\
\hline \multicolumn{7}{|c|}{ Minutes per foraging hour } \\
\hline Searching & $16(10-22)$ & $4(3-6)$ & $*$ & $1(0-1)$ & $0(0-0)$ & * \\
\hline Activity & $18(12-24)$ & $6(5-8)$ & $*$ & $1(0-2)$ & $1(0-3)$ & - \\
\hline Visual Contact & $3(2-6)$ & $7(5-9)$ & * & $9(5-15)$ & $17(0-34)$ & - \\
\hline
\end{tabular}

We determined medians and 95\% confidence intervals by Walsh averages, used the Kruskal-Wallis test for multiple comparisons, and determined confidence intervals for the binomial data by the Clopper-Pearson method (Hollander \& Wolfe 1973). Throughout the results, statements regarding comparisons, such as increased or decreased response rate, refer to significant differences $(\mathrm{P} \leq 0.05)$.

\section{Results}

Largemouth bass captured the same number of minnows and bluegills during $1 \mathrm{~h}$, but captured more minnows than bluegills during $24 \mathrm{~h}$ in the $50 \%$ cover (Table 1). They also switched foraging strategies (as indicated by changes in activity) as prey type changed. Searching occupied $70-90 \%$ of bass activity and bass spent more time searching for bluegills than for minnows. Visual contact of largemouth bass with bluegills was lower than with fathead 
minnows. Minnows seemed easier to find and capture than bluegills. Given the choice of habitat, their location also changed with prey type (Table 2). They spent most of their time in the cover regardless of prey, but more time when foraging on fathead minnows than on bluegills. Periods of activity and prey captures were split between areas of open and cover.

Northern pike behavior did not change with prey type (Table 1). Pike captured similar numbers of bluegills and fathead minnows. Northern pike spent little time searching for and following blue-gills or minnows. Pike activity, unlike that of large-mouth bass, remained low regardless of prey type. The foraging strategy of northern pike was less flexible than that of largemouth bass; pike were primarily ambushers. Bass followed, attacked, and captured more prey during the foraging hour than did pike, but both predators captured similar numbers over 24 h. Visual contact of pike with prey was higher than that of bass, but capture rates did not correspond to this difference. More than $70 \%$ of total visual contact time of pike was spent motionless but observing prey. Northern pike location also differed from that of largemouth bass. Pike spent nearly all of their time in the cover regardless of prey (Table 2). Foraging time was spent in quick bursts to capture prey that were in cover, rather than in the open areas, regardless of prey species. The response of prey to predators and their ability or inability to use the artificial plants as visual barriers may account for differences in prey encounters or captures. Without a predator, about $30 \%$ of the bluegills schooled (Table 3). Schooling by bluegills was unaffected by the presence of bass but was reduced to about $0 \%$ in the presence of a pike. In contrast to bluegills, schooling behavior of minnows was not affected by the presence of pike as compared to schooling in the absence of predators, but increased to about $70 \%$ in the presence of bass. Bluegill schooling was only affected by pike whereas minnow schooling was only affected by bass.

Table 2. Total times of observation and activity ( $\mathrm{min}$ ), and capture rate (medians and $95 \%$ confidence intervals) for predators in open or cover areas during $1 \mathrm{~h}$ feeding experiments. $\mathrm{P}=$ significance of difference in results with minnows or bluegills as prey: $*=\mathrm{P} \leq 0.05,-=\mathrm{P}>0.05$. For each prey species, 8 experiments were conducted with largemouth bass and 6 with northern pike.

\begin{tabular}{|c|c|c|c|c|c|c|}
\hline & \multicolumn{3}{|c|}{ Largemouth bass } & \multicolumn{3}{|c|}{ Northern Pike } \\
\hline & Bluegill & Minnow & $P$ & Bluegill & Minnow & $\mathbf{P}$ \\
\hline \multicolumn{7}{|c|}{ Total time } \\
\hline Open & $18(9-30)$ & $5(2-9)$ & * & $3(0-29)$ & $0(0-13)$ & - \\
\hline Cover & $42(30-51)$ & $55(51-58)$ & * & $57(31-60)$ & $60(47-60)$ & - \\
\hline \multicolumn{7}{|l|}{ Activity } \\
\hline Open & $10(6-12)$ & $2(1-3)$ & ${ }^{*}$ & $0(0-2)$ & $0(0-1)$ & - \\
\hline Cover & $9(5-12)$ & $4(3-5)$ & * & $1(0-1)$ & $1(0-1)$ & - \\
\hline \multicolumn{7}{|l|}{ Captures } \\
\hline Open & $3(2-5)$ & $2(1-3)$ & - & $0(0-0)$ & $0(0-1)$ & - \\
\hline Cover & $1(0-2)$ & $2(1-3)$ & - & $2(0-3)$ & $1(0-1)$ & - \\
\hline
\end{tabular}

Prey location in open or cover areas nearly always differed with the species of prey and predator. Without a predator, little more than half of the bluegills (median $=65 \%, n=48$ observations) were in the cover. Almost all bluegills (median $=100 \%, \mathrm{n}=96$ ) were in cover 
when a bass was present, and most (median $=82 \%, \mathrm{n}=72$ ) stayed in cover when a pike was present. In the presence of bass, fewer minnows (median $=60 \%, \mathrm{n}=96$ ) remained in the cover. Most minnows were in cover in the absence of a predator (median $=90 \%, \mathrm{n}=48$ ) or in the presence of a pike (median $=92 \%, \mathrm{n}=72$ ). Pike thus did not influence minnow location and only slightly influenced bluegill location. Bass had the greater effect on both prey species, increasing the number of bluegills in cover but reducing the number of minnows there.

Distance between the predator and the closest prey also changed with species. Bluegill schooled farther $(>\operatorname{lm})$ than minnows did $(<\mathrm{lm})$ from largemouth bass or northern pike (Table 3$)$. Individual dispersed bluegills and minnows were closer to pike $(<0.5 \mathrm{~m})$ than to bass $(>0.5 \mathrm{~m})$. Attack ranges of predators were not affected by prey type or behavior but did change with predator. Bass attacked prey at $0.3 \mathrm{~m}$ away $(0.25-0.35 \mathrm{~m}, 95 \%$ confidence interval, $\mathrm{n}=58)$. Pike attacks were only $0.15 \mathrm{~m}$ away $(0.1-0.2 \mathrm{~m}, 95 \%$ confidence interval, $\mathrm{n}=15)$ and were closer than the bass attacks.

Schooling did not always reduce the number of prey attacked by either predator. Largemouth bass and northern pike captured both schooled and dispersed bluegills without preference. About $50 \%$ of the bluegills attacked by bass $(52 \%, \mathrm{n}=44)$ and pike $(60 \%, \mathrm{n}=5)$ were schooled. Unlike bluegills, schooled minnows were attacked less often than dispersed minnows. Only about $30 \%$ of the minnows attacked by bass $(35 \%, n=46)$ or pike $(27 \%, n=11)$ were schooled.

\section{Discussion}

Predators can forage successfully in heterogenous habitats containing open and densely vegetated areas. Largemouth bass were unable to capture bluegills in uniform stem densities of 250 or 1000 stems $\mathrm{m}^{-2}$ (Savino \& Stein 1982). Yet in this study, bass captured bluegills in 50\% cover, containing an average density of 500 stems $\mathrm{m}^{-2}$ in the pool and a density of $1000 \mathrm{stems}^{-2}$ in the patch of vegetation. Plant cover often decreases encounter rate (Anderson 1984, Hershey 1985 ) or predation rate (Coull \& Wells 1983). However, as indicated by the number of follows, the encounter rate of bass with bluegills in $50 \%$ cover was twice that in $100 \%$ cover at 250 or 1000 stems $^{-2}$ (Savino \& Stein 1988). In 50\% cover, bluegills dispersed in the cover

Table 3. Prey response to predators as a function of prey schooling and distance between predator and closest prey not attacked. Medians and 95\% confidence intervals (CI) presented. Number of observations (N) in parentheses. NA $=$ not applicable.

\begin{tabular}{|c|c|c|c|c|c|c|c|c|c|}
\hline \multirow[t]{3}{*}{ Prey/Predator } & \multicolumn{3}{|c|}{ Schooling (\%) } & \multicolumn{6}{|c|}{ Distance $(\mathrm{m})$ to prey not attacked } \\
\hline & \multirow[b]{2}{*}{ Median } & \multirow[b]{2}{*}{$\mathrm{CI}$} & \multirow[b]{2}{*}{$\mathbf{N}$} & \multicolumn{3}{|l|}{ Schooled } & \multicolumn{3}{|c|}{ Dispersed } \\
\hline & & & & Median & $\mathrm{Cl}$ & $\mathrm{N}$ & Median & $\mathrm{Cl}$ & $\mathrm{N}$ \\
\hline Bluegill/None & 31 & $15-50$ & $(48)$ & NA & & & NA & & \\
\hline Bluegill/Bass & 35 & $30-40$ & (96) & 1.2 & $1.0-1.3$ & $(81)$ & 0.8 & $0.7-1.0$ & (87) \\
\hline Bluegill/Pike & 0 & $0-12$ & $(72)$ & 1.2 & $0.8-1.6$ & (18) & 0.4 & $0.3-0.4$ & (70) \\
\hline Minnow/None & 40 & $15-48$ & (48) & NA & & & NA & & \\
\hline Minnow/Bass & 68 & $60-70$ & (96) & 0.9 & $0.8-1.0$ & (89) & 0.7 & $0.6-0.8$ & (83) \\
\hline Minnow/Pike & 48 & $38-52$ & (72) & 0.8 & $0.7-1.0$ & (69) & 0.4 & $0.4-0.4$ & (67) \\
\hline
\end{tabular}


with predators, and bass captured the few bluegills that strayed into the open. Pike also captured more bluegills in $50 \%$ cover with 500 stems m m $^{-2}$ than in $100 \%$ cover with 250 or $1000 \mathrm{stems} \mathrm{m}^{-2}$ (Savino \& Stein 1988), but captured those that approached closely in the cover. Bluegills concentrated in the cover and were closer to pike in 50\% cover than in $100 \%$ cover with 250 or 1000 stems $\mathrm{m}^{-2}$. Bass are more active and have deeper bodies than pike, increasing their likelihood of being observed by prey. Pike were immobile until they attacked, and bluegills were not warned of their presence until they were well within the striking range of $0.15 \mathrm{~m}$. Quick attacks can be effected without alerting even schooled prey (Grobecker 1983).

Foraging success in 50\% cover varied with prey type. More minnows than bluegills were eaten daily by both largemouth bass and northern pike. Tiger muskellunge (Fl hybrid of muskellunge E. masquinongy and northern pike) also captured minnows more easily than bluegills (Moody et al. 1983). Generally, schooling aids prey in observing and avoiding predators (Radokov 1973, Seghers 1974, Treisman 1975) and is a common defense reaction in minnows (Sullivan \& Atchison 1978, Pitcher 1983). Minnows schooled more than bluegills but were closer to predators. Minnows preferred open areas in the presence of a mobile predator (largemouth bass) and stayed in cover in the presence of a relatively immobile one (northern pike). Even when dispersed, minnows moved continually and eventually wandered within striking distance of the ambush predator. Similar behavior was noted in another minnow, Phoxinus phoxinus, in the presence of northern pike and described as inspection visits by single or schooled minnows to ascertain the status of the predator (Magurran \& Pitcher 1987). Regardless of location or behavior, fathead minnows were observed and captured in these small, confined laboratory studies. Factors other than visual contact with prey, such as the number of strikes needed per capture (Minello \& Zimmerman 1983) or the presence of prey that are oblivious to predators and wander within striking distance, may be important in determining capture success of predators in patches of vegetation.

Predators such as largemouth bass or northern pike prefer heavily vegetated sites because of the relatively high prey abunance. Prey that are attracted to structure become concentrated in vegetation (Prince \& Maughan 1979), thereby increasing encounter rates with, and vulnerability to, foragers that also reside there. Predation rate is reduced as structural complexity increases and the number of prey remains constant (Glass 1971, Savino \& Stein 1982), but it can be maintained at adequate levels if prey numbers are increased in vegetated sites. Intermediate structural complexity, often demonstrated with homogeneous plant distributions, is predicted to optimize feeding rate (Crowder \& Cooper 1979). Similarly, our heterogeneous habitats, containing densely vegetated and open areas, can enhance feeding rates by providing areas with large numbers of prey. Rather than searching in open water and pursuing prey, predators can reduce energy costs by sitting in vegetation and waiting until prey pass nearby. Thus, in vegetation patches of littoral zones, predators are provided areas from which to ambush prey as well as areas containing high densities of prey.

\section{Acknowledgements}

This work was completed in partial fulfillment of the requirements for a $\mathrm{Ph}$. D. at The Ohio State University, Columbus, Ohio. Funding for this project was provided by Dingell-Johnson project F-57-R administered through the Ohio Division of Wildlife. We especially thank Todd Crowl, Judy Lamia, and Wayne Turner for technical assistance provided during the study. Gary Eck, Gene Helfman, Mary Henry, and Pat Hudson reviewed earlier versions of this 
manuscript. Contribution number 707 of the National Fisheries Research Center -Great Lakes, U.S. Fish and Wildlife Service, 1451 Green Road, Ann Arbor, Michigan 48105, USA.

\section{References cited}

Anderson, O. 1984. Optimal foraging by largemouth bass in structured environments. Ecology 65: 851-861.

Butler, M.J., IV \& R.A. Stein. 1985. An analysis of the mechanisms governing species replacements in crayfish. Oecologia 66: 168-177.

Chapman, C.A. \& W.C. MacKay. 1984. Direct observation of habitat utilization by northern pike. Copeia 1984: 255-258.

Colle, D. E. \& J .V. Shireman. 1980. Coefficients of condition for largemouth bass, bluegill, and redear sunfish in hydrilla-in-fested lakes. Trans. Amer. Fish. Soc. 109: 521-531.

Coull, B.C. \& J.B.J. Wells. 1983. Refuges from fish predation: experiments with phytal meiofauna from the New Zealand rocky intertidal. Ecology 64: 1599-1609.

Crowder, L.B. \& W.E. Cooper. 1979. Structual complexity and fish-prey interactions in ponds: a point of view. pp. 2-10. In: D.L. Johnson \& R.A. Stein (ed.) Response of Fish to Habitat Structure in Standing Water, North Central Division, Amer. Fish. Soc. Spec. Publ. 6, Bethesda.

Diana, J.S., W.S. Mackay \& M. Ehrman. 1977. Movements and habitat preference of northern pike (Esox lucius) in Lac Ste. Anne, Alberta. Trans. Amer. Fish. Soc. 106: 560-565.

Fish, P.A. \& J. Savitz. 1983. Variations in home ranges of largemouth bass, yellow perch, bluegills, and pumpkinseeds in an Illinois lake. Trans. Amer. Fish. Soc. 112: 147-153.

Gilinsky, E. 1984. The role of fish predation and spatial heterogeneity in determining benthic community structure. Ecology 65: 455-468.

Glass, N.R. 1971. Computer analysis of predation energetics in the largemouth bass. pp. 325-363. In: B.C. Patten (ed.) Systems Analysis and Simulation Ecology, volume 1, Academic Press, New York.

Grobecker, D.B. 1983. The 'lie-in-wait' feeding mode of a cryptic teleost, Synanceia verrucosa. Env. Biol. Fish. 8: 191-202.

Hackney, P. A. 1979. Influence of piscivorous fish on fish community structure of ponds, pp. 111-121. In: H. Clepper \& R.H. Stroud (ed.) Predator-Prey Systems in Fisheries Management, Sport Fishing Institute, Washington, D.C.

Hershey, A.E. 1985. Effects of predatory sculpin on the chironomid communities in an arctic lake. Ecology 66: 1131-1138.

Hobson, E.S. 1979. Interactions between piscivorous fishes and their prey. pp. 231-242. In: H. Clepper \& R.H. Stroud (ed.) Predator-Prey Systems in Fisheries Management, Sport Fishing Institute, Washington, D.C.

Hollander, M. \& D.A. Wolfe. 1973. Nonparametric statistical methods. John Wiley and Sons, New York. 503 pp.

Mauck, W.L. \& D.W. Coble. 1971. Vulnerability of some fishes to northern pike (Esoxlucius) predation. J. Fish. Res. Board. Can. 28: 957-969.

Magurran, A.E. \& T.J. Pitcher. 1987. Provenance, shoal size and the sociobiology of predator-evasion behaviour in minnow shoals. Proc. R. Soc. Lond. B 229: 439-465.

Minello, T.J. \& R.J. Zimmerman. 1983. Fish predation on juvenile brown shrimp, Penaeus aztecus Ives: the effet of simulated Spartina structure on predation rates. J. Exp. Mar. Biol. Ecol. 72: 211-231.

Ming, A. 1974. Regulation of largemouth bass harvest with a quota, pp. 39-53. In: J.L. Funk (ed.) Symposium on Over-harvest and Management of Largemouth Bass in Small Impoundments, North Central Division, Amer. Fish. Soc. Spec. Publ. 3, Bethesda.

Mittelbach, G.G. 1981. Foraging efficiency and body size: a study of optimal diet and habitat use by bluegills. Ecology 62: 1370-1386.

Moody, R.C., J.M. Helland \& R.A. Stein. 1983. Escape tactics used by bluegills and fathead minnows to avoid predation by tiger muskellunge. Env. Biol. Fish. 8: 61-65.

Nyberg,D.W. 1971. Prey capture in the largemouth bass. Amer. Midi. Nat. 86: 128-144.

Pitcher, T.J. 1983. Heuristic definitions of fish shoaling behaviour. Anim. Behav. 31: 611-613.

Prince, E.D. \& O.E. Maughan. 1979. Attraction of fishes to tire reefs in Smith Mountain Lake, Virginia, pp. 19-25. In: D.L. Johnson \& R.A. Stein (ed.) Response of Fish to Habitat Structure in Standing Water, North Central Division, Amer. Fish. Soc. Spec. Publ. 6, Bethesda.

Radakov, D.V. 1973. Schooling in the ecology of fishes. Translated from Russian by H. Mills. John Wiley and Sons, New York. 173 pp. 
Rahel, F.J. 1984. Factors structuring fish assemblages along a bog lake successional gradient. Ecology 65: 12761289.

Saiki, M.K. \& J.C. Tash. 1979. Use of cover and dispersal by crayfish to reduce predation by largemouth bass. pp. 44-48. In: D.L. Johnson \& R.A. Stein (ed.) Response of Fish to Habitat Structure in Standing Water, North Central Division,

Amer. Fish. Soc. Spec. Publ. 6, Bethesda. Savino, J.F. \& R.A. Stein. 1982. Predator-prey interaction between largemouth bass and bluegills as influenced by simulated, submersed vegetation. Trans. Amer. Fish. Soc. Ill: $255-266$.

Savino, J.F. \& R.A. Stein. 1988. Behavioural interactions between fish predators and their prey: effects of plant density. Anim. Behav. (in press).

Schramm, H.L., Jr. \& A.V. Zale. 1985. Effects of cover and prey size on preferences of juvenile largemouth bass for blue tilapias and bluegills in tanks. Trans. Amer. Fish. Soc. 114: 725-731.

Seghers, B.H. 1974. Schooling behavior in the guppy (Poecilia reticulata): an evolutionary response to predation. Evolution 28: 486-489.

Stein, R.A. 1977. Selective predation, optimal foraging, and the predator-prey interaction between fish and crayfish. Ecology 58: 1237-1253.

Sullivan, J.F. \& G.J. Atchison. 1978. Predator-prey behavior of fathead minnows, Pimephales promelas, and largemouth bass, Micropterus salmoides, in a model ecosystem. J. Fish.Biol. 13: 249-253.

Tomcko, C.M., R.A. Stein \& R.F. Carline. 1984. Predation by tiger muskellunge on bluegill: effects of predator experience, vegetation, and prey density. Trans. Amer. Fish. Soc. 113:588-594.

Tonn, W.M. \& J.J. Magnuson. 1982. Patterns in the species composition and richness of fish assemblages in northern Wisconsin lakes. Ecology 63: 1149-1166.

Treisman, M. 1975. Predation and the evolution of gregariousness. I. Models for concealment and evasion. Anim. Behav. 23: 779-800.

Werner, E.E., J.F. Gilliam, D.J. Hall \& G.G. Mittelbach. 1983. An experimental test of the effects of predation risk on habitat use in fish. Ecology 64: 1540-1548. 